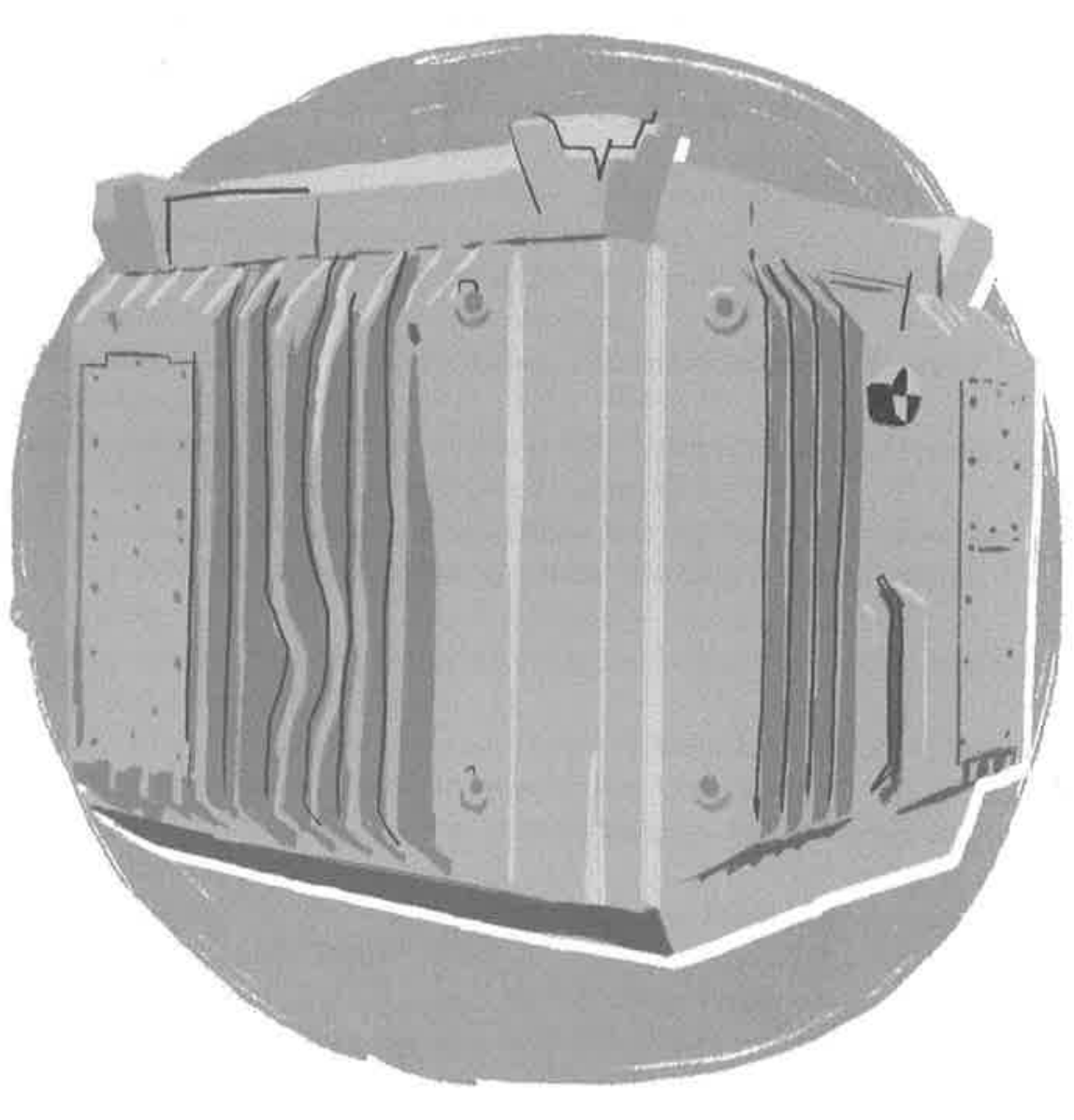

\title{
Touring the nuclear sublime: Power-plant tours as tools of government
}

Tristan Loloum

Going on a guided tour in a nuclear power station doesn't sound like a first choice for a holiday destination. The mere mention of such an excursion often triggers reactions of surprise and sarcasm ('You can actually visit these places?', 'Did you come out glowing?'). Indeed, many people ignore the fact that most nuclear stations are open to visitors, whether through information centres, guided tours or open days. In France, the electric utility company Electricité de France (EDF) has long been 'the most visited company', with more than 400,000 visitors every year. The largely state-owned company has always been a leading actor ${ }^{1}$ in the promotion of so-called 'industrial tourism' (Otgaar 2010) and 'company visits' (Morice 2006), conferring to nuclear power plants a central part in the touristic display of the nation's fleurons de lindustrie ('industrial jewels'). In Great Britain, nuclear stations have had information centres since their early days, but most of them closed in the 2000s because of British Energy's financial troubles and anti-terrorist restrictions. Guided tours and visitor centres eventually reopened in 2013, four years after EDF Energy (EDF's subsidiary in the UK) took control of British Energy and its eight nuclear power plants. They are today one of EDF's main public-relations apparatus.

This contribution focuses on guided tours and visitor centres in two EDF Energy power plants in Northern England (Heysham 2 and Hartlepool), analysing the underlying communication process at stake in the encounter between the public and a sensitive industrial infrastructure. ${ }^{2} \mathrm{~A}$ first set of arguments exposed in this chapter examines these tours as a 'sublime 
experience, defined here as an aesthetic of grandeur that transcends beauty, with mixed feelings of awe and wonder, perplexity and fascination. Just like the 'agreeable kind of horror' that filled Joseph Addison's mind when his Grand Tour went through the Alps (Addison 1773), David Nye (1994) has applied the 'technological sublime' to the sensation of vertigo experienced when facing great man-made monuments, like the Golden Gate Bridge, the Hoover Dam or Fifth Avenue. My main hypothesis is that power station guided tours aim to frame this sublime experience in order to defuse the fear of atomic risk while emphasizing popular fascination for industrial gigantism and engineering achievements. I show that most important messages are delivered during the visits through non-verbal communication: for instance, through gazing devices installed in the factory both for surveillance and aesthetic contemplation, through repeated security checks that inspire a sense of authority and control, through company-supplied protective clothing and equipment that conveys a sense of familiarity and empathy with the factory and its workers and so on.

A second point developed in this chapter suggests that EDF's visitor policy is part of a wider public-relations strategy - interpreted by French anthropologist Sezin Topçu (2013) as an 'art of governing a contested technology' - that consists in 'internalizing' anti-nuclear criticism (instead of avoiding or confronting it) by recruiting social science and environmental experts. Guided tours follow the same kind of governmental logic in the sense that they stage a paradoxical concern for 'transparency' and 'openness', suggesting to visitors that the company has 'nothing to hide.' This is a suggestion that seems contradictory, as safety measures and industrial secrecy do imply significant informational and access restrictions. Besides, how could we - as mundane visitors - make an objective assessment of such complex issues (and invisible to the eye) as radioactivity or carcinogenic hazard?

While exploring the concepts of nuclear 'sublime' and 'governmentality', the touring of a nuclear power plant reminds us of the ambivalence of tourism. On the one hand, there is its productive relation with enchantment, the imaginary and the sacred: tourism as a 'modern magic' (Picard 2013). On the other, there is its power of conformation, commodification and control: tourism as an apparatus of surveillance (Hollinshead 1999). More than a mere communication tool for corporate discourse, it should be noted that 'energy tourism' lays on a variety of cultural meanings, embodied emotions and material interests (Winthereik, Maguire and Watts 2019).

\section{The technological sublime}

The sublime is a fugitive emotion, based on mixed feelings of 'awe and reverence' (Marx 1964) but also a historically and socially situated frame of mind. What is astonishing for one person may be commonplace for another; what was yesterday's enchantment may become tomorrow's banality. Electricity lends itself very well to this complex of emotions: it is almost invisible, yet it lights millions of homes; it is formless, made of infinitely small moving electrons, yet it flows through gigantic static structures; it is destructive when passed through the body, yet it breathes life into cities and states.

In the American Technological Sublime (1994), David E. Nye analyses the American transference of the notion of the sublime from nature to technology and infrastructure. While nineteenth-century naturalists and artists have drawn extensively upon the 'natural sublime' - an emotional reaction to a natural landscape so impressive as to render a spectator speechless before its startling transcendence of ordinary experience (Burke 1909; Kant 1914) - Nye argues that twentieth-century Americans have repeatedly experienced sublimity through great technological achievements like bridges, dams, railroads or the atomic bomb. Unlike the natural sublime, the technological sublime is seldom experienced in solitude but rather as an event 'organized for crowds of tourists' (Nye 1994, 43). As such, the collective semiotics and embodied experience of the technological sublime can 'weld society together' (Nye 1994, xiii). It is no accident that in the United States, most impressive engineering works are inaugurated on the Fourth of July holiday. More than a matter of aesthetics, the technological sublime served as a specific kind of semiotics that shaped the American national identity:

Where Kant had reasoned that the awe inspired by a sublime object made men aware of their moral worth, the American sublime transformed the individual's experience of immensity and awe into a belief in national greatness. (Nye 1994, 43)

In his previous work, Electrifying America (1990), David Nye referred to the 'electrical sublime' as the spectacular illumination of world fairs and civic ceremonies, the embellishment of nocturnal cityscapes and the highlighting of singular buildings, bridges and emblematic avenues ('Great White Ways'):

The illumination was at once a marvelous tourist attraction, an advertisement for electrification, and a new form of the technological sublime, one in which a technology did not displace or conquer nature but rather intensified it ... striking the public dumb with amazement. (Nye 1990, 391) 
Electricity is here equated to one of its most visible outputs: lighting. The production of electricity itself is covered in another chapter on the 'industrial sublime' (Nye 1994, 109-42), in which Nye develops the idea that each form of power generation bears a distinct relationship to the sublime. Unlike the grimy, fuming, coal-fired, steam-driven factories, located along railway lines and run by cohorts of industrial workers, electrified (hydropower and nuclear) plants seemed to require 'virtually no workers' while being much larger and more productive, suggesting a 'quiet, streamlined, antiseptic industrial landscape' (Nye 1994, 133). Filled with anti-utilitarian meanings, hydropower dams soon became 'major tourist sites.' The Hoover Dam, probably the most emblematic hydro-infrastructure in the United States, was given evocative names like 'the Great Pyramid of the American Desert' or the 'Ninth Symphony of our day' by the American writer Frank Waters. Dams have always had a strong connection with tourism in mountain regions, not only because they enabled the opening of remote valleys through access roads and electrification but also because integration with scenic landscapes has always been a key element of their design (Rodriguez 2012). By combining the natural and technological sublime, they have become cornerstones of mountain imaginaries, major tourist attractions and places of aesthetic wonder. ${ }^{3}$

\section{Sublime tourists and nuclear power}

The 'nuclear sublime' has often been associated with the atomic bomb and nuclear accident sites and, to a lesser extent, with civil nuclear energy. For Frances Ferguson (1984), the essential attribute of the sublime is that it allows oneself to 'think the unthinkable' (Ferguson 1984, 5); it is in the 'thing that is bigger than any individual, and especially bigger in terms of being more powerful and usually, more threatening. What distinguishes beauty from sublimity is therefore the possibility of control over the observed object: 'We love the beautiful as what submits to us, while we fear the sublime as what we must submit to'. Because atomic power includes the possibility of our own annihilation (the 'nuclear holocaust'), our fascination with the nuclear is an ontological paradox. Just like suicide, 'taking one's own death into one's own hands', the nuclear sublime is 'the outcome of the subject's search for self-determination ... the achievement of a freedom from the conditions of existence by means of one's nonexistence' (Ferguson 1984, 6).
Conversely, David Nye rejects the possibility of a nuclear sublime precisely because its annihilating power contradicts Burke's classic definition of the sublime, which presupposes a sense of personal security: 'One was exposed to the power of the hurricane, but nevertheless one saw it in relative safety' (Nye 2014, 255). Even with civil nuclear energy, 'it proved difficult to separate attitudes toward reactors from fear of the bomb' (Nye 2014, 235). He therefore considers nuclear tourism as 'implausible. And when acknowledging that 'Three Mile Island became a popular tourist site in the 1980s', he views it as a 'curious irony' and a momentary craze of tourists 'on the outlook for novelties' (Nye 2014, 237).

Nick Rush-Cooper (2013) takes another path in his research on the tourism experience in Chernobyl. First, in relation to the notion of safe distance and subject/object separation, he argues that it is the embodied experience of radioactivity that triggers the reflexive 'Chernobyl Sublime', as tourists measure it through the exclusion zone with a Geiger counter. He shares this point with Goatcher and Brunsden's Chernobyl and the Sublime Tourist (2011), in which the sublime lies in an experience of place, a 'disenfranchisement of the senses' (Beck 1995) that cannot be captured by photographs. Next, while following Nye's analysis of the sublime as a historical object (rather than a universal feeling, according to Burke and Kant), Rush-Cooper deviates from Nye's dismissal of tourists as being sublime-seekers and tourism being anything other than an 'art of imitation'. For Rush-Cooper, tourism is 'performative' in the sense that it participates in the production of place, and therefore the production of sublimity - apart from being (and not contradictorily so) 'an interesting and fun day out' (Rush-Cooper 2013, 150).

As we can see, tourism has an ambivalent relationship to the sublime. For Daniel Boorstin (1964), tourism is presented as the antithesis of the modern encounter between travellers and nature. Pointing out that 'travel' came from 'travail', hence a necessary troublesome and laborious engagement with the landscape, Boorstin decries the passive stance of the contemporary 'packaged' tourist, who avoids risk and expects everything to be done for him or her. Unlike the sublime experience, a momentous experience which 'fills the mind with grand ideas and turns the soul in upon itself' (Nye 1994, 6), tourism is presented as a succession of 'pseudo-events', artificial scenes whose only purpose is mundane consumption. To some extent, David Nye shares this denial of tourism as an 'authentic' experience. Drawing on reports of early travellers to Niagara Falls and the Grand Canyon, he suggests that 'excessive tourism' leads 
to an 'erosion' and an 'eclipse' of the sublime (Nye 1994, 8). The main reason for that is the preconceptions disseminated by the tourism industry:

Ordinarily, the visitor does not see the Grand Canyon or any other site with unprepared eyes. Most sublime objects have become tourist sites. Their existence has been well advertised in advance, their appearance has been suggested by photographs, and their meaning has been overdetermined. As a result, in many cases tourists do not experience the sublime at all. (Nye 1994, 13)

Instead, they experience 'like many modern tourists' what he calls an 'inversion' or an 'egotistical sublime' (Weiskel 1986), a disjunction between expectations and reality, 'leading to a disappointment' (Nye 1994, 14).

This common disdain for tourists has already been called into question by early tourism anthropologists like Dean MacCannell (1976), whose neoDurkheimian interpretation of tourism as a modern day 'quest for authenticity' tends to reconcile tourists with the sublime. In a world that is increasingly desacralized, the enchanted encounter with new Others and new landscapes is presented as a way to reinvest daily life with transcendent significance. Nelson Graburn (1978) associates tourism with a 'sacred journey' because it mimics the three-stage symbolic structure of any rite de passage: departure, liminality (or communitas), reintegration. The tourism sublime may therefore happen in these liminal moments, emerging from the collision of a well-adjusted daily routine (the profane) and the anomic context of holiday-making (the sacred) fuelled by spectacular views, unfamiliar sensations and ontological alterity. Obviously, not all tourists invest the same sensibility in this 'sacred journey', and just as it seems unfair to presume that in many case tourists do not experience the sublime at all, it would be somewhat naive to believe that every single traveller is a fullblown aesthete, struck by awe-inspiring visions in every getaway. It also seems unfair to consider that tourism necessarily impoverishes aesthetical experience by 'staging authenticity' (MacCannell 1973) or by marketing landscape and culture. Just as there is a plurality of tourist types, there is a plurality of ways of organizing tourism, and much sublime experience is made possible because of tourism itself and the efforts of creation made by its promoters.

\section{The genealogy of openness}

In France, the first 'nuclear tours' date back to the 1970s, when the government officially launched its nuclear programme. Welcoming visitors into the nuclear factory was part of a new public-relations strategy aiming to build the image of a friendly and transparent company. At that time, civil nuclear energy was a flagship of the post-war French industry, and industrial accidents had not yet tarnished its image. 'It was a time of nuclear enthusiasm, if not nuclear utopia', comments Fanny Lopez $(2014,70)$, who traced the genealogy of public access in EDF nuclear stations. This open policy resonates with the architecture of nuclear factories. Unlike hydropower dams located in spectacular landscapes, which made hydraulics engineers more sensitive to architectural design, the first nuclear stations were built by heat engineers applying the model of thermal power stations, that is, in a purely utilitarian way. In 1974, the Executive Board launched the 'Plan Architecture' in order to develop a 'specific language of nuclear architecture' (Bouvier and Parent 2005, 7). For the first time, architects worked alongside engineers on the design of future power plants. Instead of hiding industrial facilities behind slopes and vegetation, the first architect involved in the Plan, Claude Parent, bet on industrial symbiosis: 'the station was not aimed to disappear, instead it had to participate in creating a new landscape' (Bouvier and Parent 2005, 7). Some projects based on industrial ecology promoted the development of farming around nuclear sites (including aquaculture at the mouth of heated effluents). Tourism and leisure activities near the stations were an integral part of this strategy, affirming nuclear energy as a rightful element of the territory. Claude Parent's designs had inspiring titles that were evocative of the symbolic power of nuclear technology: for example, Tutankhamun's Feet and The Tiger's Pawn. At that time, nuclear architecture echoed a certain form of sacralization of the atom - typical of the post-world-war context as well as the sublime - that identified power stations as 'cathedrals of the twentieth century' (Bouvier and Parent 2005, 7).

But this enthusiasm was soon cooled by a growing anti-nuclear protest and the 'anthropological shock' (Beck 1987) caused by the Three Mile Island (1979) and Chernobyl (1986) accidents. As mentioned by Sezin Topçu in her monograph La France Nucléaire (2013) on the government of nuclear energy in France, some EDF communications experts considered that such sacralization served the cause of anti-nuclear movements by reinforcing the idea of nuclear energy as a Promethean technology, fundamentally uncontrollable by ordinary humans. Specialists advocated a 'desacralization of nuclear issues' so as to normalize its role in the electricity supply chain and reduce the perception of nuclear risks. It was also in this period that EDF mandated research groups of linguists, semiologists and sociologists to think about the most efficient communication strategies. Gone were the 'cathedrals'; nuclear power stations were renamed 
'steam engines of the twentieth century'. Still, according to Topçu, 'guided tours in nuclear power stations are launched in this context, in order to break with the idea that nuclear plants are inaccessible "sanctuaries" to the public. They will give birth to a proper nuclear tourism with approximately 300,000 visitors a year' (Topçu 2013, 200, my translation). Ever since, visits have become an important public-relations tool to produce a controlled yet 'open and transparent' image of the nuclear industry. In the 1990s, terrorist threats ${ }^{4}$ and economic difficulties experienced by the group (in a context of market deregulation) caused other problems. Today, visitors must book at least three weeks in advance and send copies of their ID for a 'security check'.

British power plants experienced a similar shift. According to Mandy, a guide at Heysham 2 since the 1990s, 'people used to just show up and we would take them on a tour. Some were just wearing flip-flops' (Mandy, participation observation September 2016). Information centres closed in the early 2000s, when British Energy was under great financial stress. The Hinkley Point $\mathrm{C}^{5}$ project was apparently the main reason to reopen visitor activities in UK power plants, now the property of EDF Energy: 'First they wanted to focus on Hinkley Point and build a big information centre there, but then they extended it to all power stations. Because it's a national project' (Mandy, participation observation September 2016). Three years after reopening, the number of visitors is increasing. According to Martyn Butler, EDF external communications manager for the Northern Region:

Hartlepool and Heysham were celebrating their 20,000th visitor in October 2016. After Hinkley, they are the second and third most visited centres across the network. As of the end of August we were at 33,208 visitors - however, this is across the whole fleet of eight visitor centres. By year end we are on track to achieve 50,000 visitors. (Martyn Butler, interview September 2016)

For the public-relations expert, an important reason for attracting tourists is 'to inform the general public on the importance of nuclear power in the energy mix of the UK' (Martyn Butler, interview September 2016). In the information centre, panels praise nuclear energy by comparing it with other sources ( $1 \mathrm{~kg}$ of coal lights up a lamp for four days, while $1 \mathrm{~kg}$ of uranium lights it up for 140 years) and by putting forward key figures for energy supply (5.5 million customers, 20 per cent of UK total energy), for the economy (15,000 jobs in EDF Energy, 6,600 jobs in nuclear power plants) and for the environment $\left(30,000,000\right.$ tons of $\mathrm{CO}_{2}$ saved). In a context of market deregulation and increasing competition among energy suppliers, all means are important to woo customers. Although many clients remain 'captive', the liberalization of markets implies that customers should be able in the future to choose the kind of energy that they want to consume. For now, as the country faces difficult decisions (namely, the Hinkley Point project), EDF's marketing strategy aims to influence public opinion. ${ }^{6}$

\section{Demonstrative safety and the controlled gaze}

Another key objective of guided tours, according to Martyn Butler, is 'to show that we are open and transparent, especially after Fukushima. We wanted to reassure people.' Safety is indeed omnipresent during the visit. When entering the site, the tone is set by a police car parked on the access road and a 5-foot concrete sign displaying EDF's corporate motto: 'Safety is our overriding priority'. On arrival, people must sign a visitor's book in the information centre. Apart from the visitor centre, photographs are prohibited everywhere, including in the parking lot. The first 10-20 minutes of the tour are exclusively dedicated to 'press the safety button', as our guide puts it. After delivering the opening remarks about safety ('How will you show commitment to nuclear safety?'), the guide invites us to put on the safety equipment: a reflective vest, a helmet with hearing protection, safety gloves and plastic glasses. This array of safety equipment gives the impression of a zealous initiation to the security-centred world of a working nuclear plant; even though some workers move about without specific safety equipment, we are instructed to keep our helmets and glasses on at all times. At Heysham, there was particular vigilance because of a planned shutdown for maintenance. I wasn't even able to bring a pen and a paper on the tour because of extra security measures. The demonstration of EDF's concern for safety isn't just a matter of speech, it's a demonstration at work, and visitors experience it personally. They must be given a perfect example of the company's commitment to security. After depositing any metal belongings in a safe, a security agent double-checks our IDs and searches us with a metal detector; after that, we are given an electronic pass and required to go individually through a safety revolving door.

Within the working sectors of the factory, the path is marked with signs and yellow lines painted on the floor. Safety messages and reminders are posted everywhere. Some of them explicitly address workers, advocating a faultless 'nuclear professionalism'. Other educational panels are specifically designed for visitors. In one of the corridors, a 20 -foot-long timeline traces the history 
of the power plant (with photographs of women guides from 1985); another highlights some EDF merchandizing (such as the group's mascot, Zingy, and the electric Mini Cooper). Visitors are taken across footbridges which allow them to enjoy the spectacle of the station without interfering with its functioning. Unlike Hartlepool and Heysham 1, Heysham 2 seemed to have been designed with a particular concern for visitors. Apart from the fact that the whole factory was built in the shape of a massive ocean liner, at least three bay windows allow visitors to gaze upon the most sensitive and scenic elements of the station: one facing the sea and the pipes used to pump and eject the cooling water, another one over the reactor chamber and the final one over a control room reminiscent of a scene from a vintage science-fiction movie. As French anthropologist Saskia Cousin noted, these gazing devices are also devices of control, similar to the Foucauldian panopticon:

Like the panopticon, the footbridge allows control over individuals: hanging over the working areas, far off, often glazed, hence soundproof, it allows visitors to see 'what's going on' in the factory while avoiding unwanted communications. (Cousin 201, 56, my translation)

While walking out of the security office, we encounter a heavily armed policeman. Like any high-security deployment, the omnipresence of safety precautions has an ambivalent effect. On the one hand, it is reassuring to see that safety is taken seriously, often to a point that no one could ever imagine. But on the other hand, the obsessive concern with security acts as a worrying reminder of the aweinspiring potentiality of nuclear hazards.

\section{The paradox of nuclear transparency}

As Sezin Topçu puts it, transparency is 'an identity-discourse of nuclear energy' (Topçu 2013, 160). Since Chernobyl, EDF has chosen to adopt a proactive strategy towards nuclear safety, by communicating in real time on the severity of industrial incidents and by making public the results of inspection measures made on the facilities. The point of issuing a press release for every incident, even the most anecdotal ones, was to better control the information, set the pace of nuclear reporting and defuse controversies upstream. Through its communications services, EDF develops a genuine nuclear pedagogy aiming 'to accustom little by little the population to the idea of an incident, to its banality, to the fact that it becomes commonplace in a risk society' (Topçu 2013, 160).
The internalization of criticism also involves new institutional forms of relationship with anti-nuclear protesters and residents, such as the Commissions Locales d'Information (CLI). Part of the criticism of nuclear energy has evolved towards a more scientific discourse. The experts-versus-laypeople divide is progressively reconfigured, as many residents develop a challenging expertise. This expertise is based on a long-term cohabitation with nuclear industries, a highly informed opinion on sanitary risk and the involvement of many independent scientists with anti-nuclear movements (de Carvalho 2013). Much could be said about the limits of such a joint expertise approach and the incompleteness of the type of transparency implemented by nuclear actors. For Sezin Topçu, there is a 'permanent paradox' - if not a certain 'hypocrisy' - behind the discourse of a 'transparent and controlled atom', as it seems impossible to communicate serenely and objectively on matters like cancer occurrences, nuclear accident scenarios and nuclear waste disposal (Topçu 2013, 182-93).

This paradox also applies to guided tours in nuclear power stations. While the possibility of a visit suggests that EDF has 'nothing to hide', there are obvious limits to such openness. We have already mentioned questions of safety, which restrain access to many parts of the factory, but we could also mention questions of industrial secrecy. Especially in a context of market pressure and strategic investments (e.g. Hinkley Point $C$ ), it is understandable that industrial managers want to filter the kind of information - beginning with photos - that come out of the visits. Other limits are cognitive and psychological; even if the company was ready to fully play the game of transparency, many aspects presented during the tour remain unintelligible for the average person without proper measurement tools. How can one be transparent when dealing with an invisible matter like radioactivity? Metaphorically, one could argue that the clear water of the spent-fuel storage pond doesn't say anything about its toxicity. Transparency is performed but never complete. The strict standards of cleanliness everywhere in the station, supposedly for safety reasons, support the idea of a clean, antiseptic industry, a 'symbol of modernity and the future', especially if compared to the dusty 'smoke-billowing coal-fired factories' (Nye 1994, 133-4). During the tour, attention is focused on the engineering aspects of the station, the spectacular arrangement of sophisticated machinery and highly skilled workers who busy themselves before our eyes like bees in a massive super-organized industrial hive. All of this is thrilling, not only intellectually but also sensorially. Eyes are filled with uncommon scenes; the labyrinthic profusion of footbridges, tubes, machinery and sectorial divisions has a disorienting effect, accentuated by the near absence of natural light and the overwhelming space of engine rooms, the 
persistent smell of concrete and the deafening noise of the turbines, attenuated by the veiled silence of ear-itching protections, and so on.

\section{Humanizing the industrial monster}

While from a tourism experience point of view, all this seems very convincing, the over-emphasis on the technicalities of the factory conveniently prevents the visitor from addressing the general issues of nuclear energy. Understandably, a nuclear power station isn't the best place to make a case against nuclear energy, but it is interesting to note that not one controversial comment or question was formulated by the visitors (including myself) during the tours. It felt inappropriate or 'taboo'. Controversial questions - such as questions relating to technological faults in new generation reactors, the company's economic difficulties and so on - were also carefully avoided in the permanent exhibition of the information centre. However, guides did not seem uncomfortable with 'political questions'. In fact, one of the first interactions I had with a guide in a nuclear station started with a 'political discussion'. I met Ray - a sixty-nine-yearold guide and a former engineer at Hartlepool station - while shuffling between the information panels in the visitor centre. When I told him I was a social scientist interested in the tourism display of energy facilities, he immediately asked me if, in my opinion, 'All this [the visitor centre] is a political thing' (Ray, participant observation May 2016). As I awkwardly avoided the question by arguing that he was probably in a better position to answer that question and that such initiatives may have many purposes (including political ones), he stated that the most important thing for him was to pass on knowledge: 'I chose to work here [as a guide] because I like sharing what I believe in ... and also because my wife kicks me out!'

This short anecdote suggests that the guides aren't necessarily uncomfortable with engaging in 'political' arguments; it is more often the visitors who are. As permanent workers in the nuclear industry, the guides have had plenty of time to think about the ethical dilemmas of their activity and prepare themselves for awkward questions. And although our group seemed too polite to engage in a controversial discussion, other visitors don't always share the same embarrassment: 'we are constantly subject to criticism', another guide told me during an informal encounter. By exposing itself to detractors, guided tours are part of EDF's strategy of openness and transparency, which consists in pre-empting criticism rather than avoiding it (Topçu 2013). The passionatehumoristic spin of Ray's response (the passion of sharing and the tyranny of spouses) also demonstrates his ability to depoliticize a debate. While the selfcensorship and the persistence of taboos suggest that nuclear stations continue to transmit a feeling of 'sacrality' among visitors, we could argue that the guides' familiarity with the factory's environment has a 'secularizing' effect.

EDF guides have close relations with the factory they work in; most of them are retired nuclear engineers (like Ray) or relatives of nuclear workers (Mandy is married to a technician). This double-familiarity - with the plant and the workers - is reassuring. The nuclear reactor is not just a cold monster of steel, graphite and plutonium; for the workers, it is simply another 'sector' among many, a few doors away from the cafeteria. Their affective relationship with technology raises empathy: Mandy calls the reactors 'she' ('because they're ladies!') and jokes about her husband's 'other wife', the diesel generator where he works. The same thing happens with safety: the guide's usual ease with the many procedures helps de-dramatize the situation. At Hartlepool, when we come across an armed policeman, Ray cracks a joke to soften the atmosphere: 'Don't worry, I told him not to shoot you. But if he does shoot you, just start running in a zig-zag!' 'The guides allow a certain intimacy between workers and visitors: While walking through the station, they hail and greet their colleagues; to explain radioprotection and radioactivity measurement routines, Ray gives one of the co-workers a pat on the back and asks him to show us his electric personal dosimeter (EDP). All these little attentions contribute to humanizing the station. They make the 'awe-inspiring' confrontation with the nuclear sublime become a banal promenade among friendly co-workers.

As we are impressed by the magnitude of the infrastructure, the casual manner of the guide takes us back to its banality; her familiarity with the place makes us 'kin' with the power plant (Haraway 2015; Winthereik, Maguire and Watts 2019). When standing at the foot of the first high-voltage pylon located at the mouth of the transformer, Mandy explains that this is the first pylon of the network after the station: 'That's where it all begins.' In the blink of an eye, my imagination travels back and forth between the far-off corners of the national grid and the concealed walls of the nuclear reactor. She says that the latest maintenance work cost more than several hundred thousand pounds. As I ask her if this pylon has a 'special name' among workers, expecting some kind of collective devotion to such an emblematic piece, she just replies in a teasing tone, 'Yeah, the big pylon!' and moves on to the next feature, laughing. 


\section{Managing human resources}

Mandy is happy to have interested and disciplined visitors: 'The vast majority are children, it's difficult to get their attention. And we must always keep an eye on them: you don't want to have kids getting lost in the turbine room.' Schools are the main source of visitors for EDF information centres. At Heysham, they represent approximately 70 per cent of the public. In the exposition, the colourful panels seem specifically designed for the children. Dispersed around the room, experiments invite visitors to discover electricity in a playful manner: by producing current with a wheel, testing different conductive materials or wiring a staircase switch. One terminal - 'On the Waves of Radiation' - is composed of two wheels that look like wheels of fortune and allows visitors to measure the radiation of commonplace radioactive materials (a camping gas light, granite, fertilizer) with a dosimeter and to compare the insulating capacity of different shield samples (wool, cloth, glass, aluminium). In another corner of the room, a video game in an arcade cabinet consists of replacing uranium bars with a handling machine as quickly as possible. Near the main entrance, flyers and brochures advertise the many EDF education programmes: The POD (EDF Energy's online education programme), apprenticeships, early careers, trainee programme and so on. With more than 13,000 employees and a growing demand for qualified engineers, visitor centres and guided tours are key instruments to attract future workers.

Company visits also fulfil internal communication purposes. From the workers' point of view, it seems that they enjoy being an object of curiosity. Some of them wave and smile as we look through the bay window above the control room or as we pass by in the corridors. As I sign the visitors' book at the entrance to the information centre, I notice the names of professionals from many partner companies. When speaking with the manager, I learn that visits are a common way to spend time after a business meeting with a client or a contractor. It is also an important opportunity for the workers' families to discover what their work environment is like. Each year the visitor centre organizes special open days for them. The transformation - even temporarily - of an industrial environment into a visitor attraction can have a legitimizing effect: the fact that people outside the organization show interest in their work may increase their self-esteem as workers and their confidence in the company's mission. Although this may appear anecdotal if compared with the many factors that influence life quality in the workplace, building a friendly united image of the company is useful for suggesting unity among a diversified and numerous workforce.

\section{Conclusion}

The genealogy of visitors' access to nuclear power plants shows that touring has been a problematic issue, not only for safety and economic reasons but also because popular representations of nuclear energy have evolved, ranging from national pride and technological vanguard to atomic disaster and sensitive target for terrorist attacks. Due to the complexity of nuclear engineering, imagination is often an intellectual 'crutch' that helps laypeople to make sense of it. The way people react in relation to nuclear energy is necessarily imbued with meanings and images, a touch of 'awe and reverence' typical of Leo Marx's (1965) first definition of the 'technological sublime. They ascribe to it an imaginary that has been fuelled by a history of military testing, atomic bombing and nuclear accidents but also by a sense of industrial grandeur, scientific novelty and technological prowess.

Ever since the first world fairs, promoters of electricity have had an ambivalent attitude towards the sublime, not only using its enchantments to sell services and spread new technologies (cf. Raoul Dufy's Fée de l'Electricité), but also trying to demystify its risks and reassure the population about its dangers. From a commercial and political point of view, the sublime is a double-edged sword: on the one hand, it can 'weld society together' and speak directly to the heart through the language of emotions (in a 'subliminal' way); on the other, it reminds us of the ontological vulnerability of the self in the face of uncontrollable forces of nature or technology. In the case of nuclear energy, this ontological insecurity seems incompatible with the ideal of a faultless safety record promoted by experts. And, while some nuclear architects have intended to build upon the sacred-leaning nuclear imaginary to conciliate the atom with a sense of aesthetic beauty (that is, controlled beauty), the efforts made by communication managers have focused on the diffusion of a secularized, rational image of nuclear infrastructure.

From the point of view of the company, visits fulfil many purposes: they serve to consolidate the role of nuclear energy in public opinion, build the image of an open transparent company, reassure local residents and attract new recruits. But this is done in a peculiar way, by passing over the mere discursive dimension of corporate communication to propose an embodied experience, 
a physical interaction with the factory and its people. Because tourism involves emotions and imagination, it is particularly helpful for the company to get the message across. EDF's guided tours tend to counter this sublime feeling by transmitting a sense of control and safety. By allowing visitors to experience the daily routine of nuclear workers, the company depicts the factory not only in functional and dispassionate terms but also in a friendly way, transforming the nuclear sublime into a banal excursion and a 'fun day out'. By exposing itself willingly to the public's curiosity and potential criticism, EDF presents itself as a 'transparent' company, while always staying in control of the terms of dialogue and the limits of accessibility. It is precisely this proactive, productive and even 'friendly' response to nuclear rejection that makes guided tours an efficient tool of government.

\section{Notes}

1 EDF published the first Guide du Tourisme Industriel et Technique in 1992, and three years later, it launched the 'Industrial and Technical Tourism Trophies' that rewards private companies for outreach initiatives towards the general public.

2 Fieldwork was conducted between May and September 2016 through participatory observation (guided tours, visits in EDF information centres) and interviews with guides and external communication managers from EDF. Most of the ethnographic material is based on two guided tour experiences: one made at Hartlepool with four fellow social scientists from Durham University, and another one at Heysham 2 with a retired couple from California who had planned a stop at Heysham while on holiday, as the husband had participated in the zoning of the second reactor when he was still working as an industrial consultant. I also benefited from complementary fieldwork in France at EDF's Hydrélec national museum, where I was able to interview the cultural mediator and to consult some of the company's archives as well as a valuable literature on EDF's history of public relations.

3 It is no coincidence that dams are regularly used as spaces for art exhibitions. It is because they raise questions about the nature/culture divide (wilderness versus domestication, landscape versus industry) and challenge our common perceptions of the landscape.

4 Visits were stopped on several occasions in the 1990s because of the anti-terrorist plan 'Vigipirate'.

5 Hinkley Point $\mathrm{C}$ is a project to construct a new 3,200 MWe nuclear power station with two European Pressurized Reactors (EPR) in Somerset, England, next to the Hinkley Point B station. The construction cost is estimated at $£ 18$ billion
( $£ 24.5$ billion including financing costs) and should be assumed by EDF together with a Chinese state-owned company (CGN). In exchange, EDF has negotiated a guaranteed fixed price - a 'strike price' - of $£ 92.50 / \mathrm{MWh}$ (in 2012 prices). After several years of harsh negotiation on both the French and the British sides, the proposal was finally approved by the EDF board in July 2016 and by the UK government in September of that year.

6 Using energy tourism as a lobbying tool is not uncommon among energy groups. Once, at another guided tour in a Swiss hydropower dam, I had the opportunity to observe similar comparisons. In one of the explanatory panels, the group states that to produce the same amount of electricity, 570 wind turbines would be necessary (34 times the surface of the water dam's reservoir). On the next one, it is said that the hydroelectric factory can be started in only 200 seconds, while a nuclear station requires weeks to be entirely switched off. Here, too, guided tours are a way to 'share the group's concerns with the public in a critical political moment' (Sarah Falcinelli, communication manager, interview May 2016), as Swiss hydropower actors are pressing the government to help the hydropower sector overcome the financial crisis caused by low energy prices (Loloum 2016).

7 Approximately every two years, nuclear stations are shut down for several weeks for maintenance. This is a busy period when many contractors converge on site. At Heysham, the parking lot was nearly full that day. This planned maintenance shutdown of the Heysham 2 reactor occurred after 940 days of continuous operation, a 'world record' according to the guide, which judging by her enthusiasm, is seen as a good thing. At Hartlepool, visits are suspended during the shutdown, probably because it is an older generation of reactor (just like Heysham 1, built in the same period).

\section{References}

Addison, Joseph. 1773. Remarks on Several Parts of Italy, \& $c$. in the Years 1701, 1702, 1703. Dublin: Printed for T. Walker.

Beck, Ulrich. 1987. 'The Anthropological Shock: Chernobyl and the Contours of the Risk Society', Berkeley Journal of Sociology, 32: 153-65.

Beck, Ulrich. 1995. Ecological Politics in an Age of Risk. Cambridge, MA: Polity Press. Boorstin, Daniel J. 1964. The Image: A Guide to Pseudo-Events in America. New York: Harper \& Row.

Burke, Edmund. 1909. On the Sublime and Beautiful, The Harvard Classics (Vols. 1-51, Vol. 24). New York: P. F. Collier \& Son.

Cousin, Saskia. 2001. 'Industrie de lévasion ou entreprise d'encadrement? Le cas du tourisme industriel', Quaderni, 44(11): 45-71. 
de Carvalho, Lucie. 2013. 'Le complexe nucléaire de Sellafield au cœur des controverses: le fait technologique entre experts et profanes', VertigO - la revue électronique en sciences de l'environnement, 13(2), doi:10.4000/vertigo.14187 (accessed 20 April 2017).

Ferguson, Frances. 1984. 'The Nuclear Sublime', Diacritics, 14(2): 4-10.

Goatcher, Jeff and Viv Brunsden. 2011. 'Chernobyl and the Sublime Tourist', Tourist Studies, 11(2): 115-37.

Graburn, Nelson H. H. 1978. 'Tourism: The Sacred Journey', in Valene L. Smith (ed.) Hosts and Guests: The Anthropology of Tourism, 17-31. Oxford: Basil Blackwell.

Haraway, Donna. 2015. 'Anthropocene, Capitalocene, Plantationocene, Chthulucene: Making Kin', Environmental Humanities, 6: 159-65.

Hollinshead, Keith. 1999. 'Surveillance of the Worlds of Tourism: Foucault and the Eye-of-Power', Tourism Management, 20(1): 7-24.

Kant, Immanuel. 1914. The Critique of Judgement. London: MacMillan and Co.

Loloum, Tristan. 2016. 'La vie touristique des grands barrages hydroélectriques', Mondes du Tourisme, 12. http://tourisme.revues.org/1360 (accessed 20 April 2017).

Lopez, Fanny. 2014. 'Les touristes du nucléaire: l'enjeu de l'accessibilité des sites de production EDF, 1974-1991'. Annales Historiques de l'Électricité, 12(1): 65-75.

MacCannell, Dean. 1973. Staged Authenticity: Arrangements of Social Space in Tourist Settings. Chicago: University of Chicago Press.

MacCannell, Dean. 1976. The Tourist: A New Theory of the Leisure Class. New York: Schocken Books.

Marx, Leo. 1964. The Machine in the Garden: Technology and the Pastoral Ideal in America. New York: Oxford University Press.

Morice, Jean-René. 2006. 'La visite d'entreprise en Europe: un champs à explorer', Cahiers Espaces, 92: 10-15.

Nye, David E. 1990. Electrifying America: Social Meanings of a New Technology, 1880-1940. Cambridge, MA: MIT Press.

Nye, David E. 1994. American Technological Sublime. Cambridge, MA: MIT Press.

Otgaar, Alexander H. J. 2010. Industrial Tourism: Where the Public Meets the Private.

Rotterdam: Erasmus Research Institute of Management (ERIM), Erasmus University Rotterdam.

Parent, Claude and Yves Bouvier. 2005. 'Architecture et paysage du nucléaire: La centrale crée le site', Annales Historiques de l'Électricité, 3(1): 7-17.

Picard, David. 2013. Tourism, Magic and Modernity: Cultivating the Human Garden. New York: Berghahn Books.

Rodriguez, Jean-François. 2012. 'Hydropower Landscapes and Tourism Development in the Pyrenees. From Natural Resource to Cultural Heritage', Journal of Alpine Research, 100(2): 2-15.

Rush-Cooper, Nicholas. 2013. Exposures: Exploring Selves and Landscapes in the Chernobyl Exclusion Zone, Durham theses, Durham University. Available at Durham E-Theses Online: http://etheses.dur.ac.uk/8490/ (accessed 20 April 2017).
Topçu, Sezin. 2013. La France nucléaire: l'art de gouverner une technologie contestee. Paris: Éd. du Seuil.

Weiskel, Thomas. 1986. The Romantic Sublime: Studies in the Structure and Psychology of Transcendence. Baltimore, MD: Johns Hopkins University Press.

Winthereik, Brit Ross, James Maguire and Laura Watts. 2019. 'The Energy Walk: Infrastructuring the Imagination', in D. Ribes and J. Vertasi (eds), Digital STS: A Field Guide for Science \& Technology Studies. Princeton: Princeton University Press. 